University of Nebraska - Lincoln

DigitalCommons@University of Nebraska - Lincoln

\title{
The Ecologically Noble Savage Debate
}

Raymond Hames

Follow this and additional works at: https://digitalcommons.unl.edu/anthropologyfacpub

Part of the Archaeological Anthropology Commons, and the Social and Cultural Anthropology Commons

This Article is brought to you for free and open access by the Anthropology, Department of at DigitalCommons@University of Nebraska - Lincoln. It has been accepted for inclusion in Anthropology Faculty Publications by an authorized administrator of DigitalCommons@University of Nebraska - Lincoln. 


\title{
The Ecologically Noble Savage Debate
}

\author{
Raymond Hames
}

Department of Anthropology and Geography, University of Nebraska, Lincoln, Nebraska 68588; email: rhames@unl.edu

Annu. Rev. Anthropol. 2007. 36:177-90

First published online as a Review in Advance on June 6, 2007

The Annual Review of Anthropology is online at anthro.annualreviews.org

This article's doi:

10.1146/annurev.anthro.35.081705.123321

Copyright (c) 2007 by Annual Reviews.

All rights reserved

0084-6570/07/1021-0177\$20.00

\section{Key Words}

conservation, hunting, human ecology

\begin{abstract}
Debate around the ecologically noble savage represents two markedly different research threads. The first addresses the issue of conservation among native peoples and narrowly focuses on case studies of resource use of ethnographic, archaeological, or historic sources. The second thread is broader and more humanistic and political in orientation and considers the concept of ecological nobility in terms of identity, ecological knowledge, ideology, and the deployment of ecological nobility as a political tool by native peoples and conservation groups.
\end{abstract}




\section{INTRODUCTION}

In April of 2005 I read Krech's (2005) assessment of reactions to his monograph The Ecological Indian (1999). In that book he concluded that little or no evidence could be found for conservation among Native Americans prior to contact and plenty of evidence demonstrated a lack of conservation during the contact period. He also provided evidence that whereas some contemporary native peoples are interested in conservation, others are not. This view is consistent with major reviews of the conservation literature in the ethnographic world (e.g., Smith \& Wishnie 2000). Ironically, in that same issue of the American Anthropologist I happened upon a book review (Stoffle 2005) addressing cultural resource management by Native Americans in which I found the following:

For tens of thousands of years, the people of the New World sustainably used and managed these very old human ecosystems.... Conservation ethics based on traditional ecological knowledge went hand in hand with the ecosystem being culturally central to the people. (p. 139)

Of course, it depends what the reviewer means by "sustainably used or managed," but it seems that it will take some time for specialist demonstrations about the rarity of conservation in any society to trickle down to workers in other areas, but it is not for want of effort. In the $A R A$ alone, during the past ten years, four chapters have been devoted to the issue of conservation. In cultural anthropology Orlove \& Brush (1996) discussed indigenous knowledge and participation in conservation efforts. Another cultural review by Smith \& Wishnie (1999) comes closest to the approach taken here. After theoretically distinguishing sustainability from conservation, they review the claims for and against conservation and identify the factors that promote and inhibit conservation. The other two articles came from archaeolo- gists. Stahl (1996) addresses the archaeology of biodiversity during the Holocene, covering natural changes (El Niño and volcanism) and anthropogenic changes in terms of hunting, burning, deforestation, and agriculturalassociated changes such as irrigation, terracing, and raised fields (see also Redman 1999). Hayashida (2005) reviews the archaeological evidence of the long-term effects that human populations have made on landscapes and biological diversity (see also the collection edited by Lyman \& Cannon 2004). Finally, debates regarding human agency in the context of extinction megafauna worldwide is an intensive area of archaeological and paleontological research. Unfortunately space limitations preclude review of this area here. Interested readers should see True et al. (2005) and Miller et al. (2005) on Australia, Surovell et al. (2005) on proboscideans worldwide, Steadman et al. (2005) on New World sloths, Stewart et al. (2004) on European neandertals, and Kelly \& Prasciunas (2007)'s excellent review and critique of Martin's overkill hypothesis for a sample of this extensive literature.

At the popular level, Diamond's best seller Collapse (2003), a case-study compendium of historic and prehistoric human-caused ecological disasters, forcefully brought the issue of environmental degradation to the general public. Borgerhoff Mulder \& Coppolillo et al. (2005) have written a superb new textbook on conservation from an anthropological perspective. To some extent ecological nobility is related to a reexamination of the so-called noble savage writ large as it relates to social egalitarianism (Boehm 1999), cultural psychology (Edgerton 1992), racism (Ellingson 2001), and peaceableness (Keeley 1995, LeBlanc 2003).

\section{HISTORY AND ORIGINS OF THE ECOLOGICALLY NOBLE SAVAGE}

According to Ellingson (2001), in his aptly titled book The Myth of the Noble Savage, the term noble savage was first used in English 
by Dryden in 1672 but originated from the New World writings of the French explorer Lescarbot in 1609. For a variety of reasons examined by Ellingson it became incorrectly associated with Rousseau and served as a critique of then modern European society. As a stereotype it was employed to highlight problems faced by modern Europeans and pointed to a way of life in which these problems were absent (Buege 1996). More important for today's debate, Nadasdy (2005, p. 298) argues that its more recent foundation began with the late nineteenth century conservationists George Bird Grinnell, Ernest Seaton, and more recently Gifford Pinchot. Grinnell had spent time with the Pawnee and Ponca, and Pinchot was familiar with Speck's ethnographic work on Algonquian family hunting territories. Both claimed that Native Americans were original conservationists. It is highly likely, but by no means established, that such claims filtered into conservation organizations who lionized these men and their philosophy became part of the dogma of many conservation organizations.

Whatever its precise origins, the idea that native peoples lived in harmony with the environment was reinforced indirectly in the field of cultural ecology through the energy flow theory of Odum (1972) and others who argued that ecosystems were tightly organized systems that tended toward equilibrium or stability. It reached a zenith in biology perhaps when Wynne-Edwards (1962) claimed that social species evolved a series of adaptations that prevented them from degrading their habitat. These theoretical streams of Odum and Wynne-Edwards along with Slobodkin's prudent predator hypothesis (1974) were then picked up by anthropologists and elaborated in the influential work of Rappaport (1983) and Meggers (1971) and, to some extent, by cultural materialists such as Harris (1968, 1974). The idea that cultures or populations were the units of selection was a key idea that united these theorists. Groups that devised stable population control mechanisms were able to out-compete those who did not.
Especially influential were their ideas about warfare as a cultural solution to the problem of resource balance. Consequently, earlier claims about native peoples living in harmony with the environment found theoretical support in cultural ecology.

The idea of indigenous harmony also made cursory empirical sense. Most environmental degradation was caused by state societies, whereas tribal peoples tucked away in tropical rainforests or deserts were seen as having little negative impact on the environment (Borgerhoff Mulder \& Coppolillo 2005). Evidence for this association is seen in several comparative studies showing an association between biodiversity and the distribution of native peoples: High biodiversity is associated with the presence of native peoples, whereas low biodiversity is associated with nonnatives (Borgerhoff Mulder \& Coppolillo 2005, pp. 81-88; see also Redford \& Robinson 1987 on native and nonnative hunting). But doubt grew in the anthropological community as empirically minded researchers attempted to evaluate such claims. Early doubters such as Rambo in his evocatively entitled ethnography Primitive Polluters (1985) and the cultural geographer Diamond (1986) presented well-documented counterexamples of either environmental indifference or destruction by tribal peoples. Others such as Smith (1983), Hames (1988, 1991), and Alvard (1994, 1998) influenced by behavioral ecology had grave doubts about group-level adaptations and provided theoretical critiques and empirical research to demonstrate that conservation occurs most likely under restricted circumstances or was not in evidence despite research designed to detect its existence. An extensive review of these efforts is presented by Smith \& Wishnie (2000).

Revisionism perhaps reached a tipping point in 1991 with the publication of Redford's (1991) "The Ecologically Noble Savage," in which he declared that the idea of deliberate conservation by native peoples was a myth (see also Stearman 1994). The development of evolutionarily and 
microeconomically informed approaches emphasizing the individual level of selection and detailed ethnographic (e.g., Alvard 1993) and historic studies (e.g., Krech 1981) of foraging and other extractive behaviors demonstrated that conservation of natural resources by native peoples either did not occur or was a side effect of low population density, simple technology, and lack of external markets to spur over-exploitation (Hunn 1982).

\section{THE MEANING OF CONSERVATION}

Much of the debate about the ecologically noble savage revolves around how conservation is defined along with the allied concepts of management and sustainability. Ruttan \& Borgerhoff Mulder (1999, p. 621) note that conservation has been defined in multiple ways depending on the discipline studying the phenomenon. For the U.S. government, "Conservation commonly refers to the maintenance of genetic, species, and ecosystem diversity in the natural abundance in which they occur (OTA 1987)"; for evolutionary ecologists, "... conservation acts are by definition costly and entail the sacrifice of immediate rewards in return for delayed ones"; and for conservation biologists "... researchers with more applied interests typically consider an intent to conserve, as evidenced by institutional design, to be sufficient."

As noted by Smith \& Wishnie (2000), conservation refers to actions that prevent or mitigate biodiversity loss and are designed to do so. The design criterion is key and was first brought to the attention of anthropologists by Hunn (1982). He distinguished epiphenomenal (or side effect) conservation from true conservation. Epiphenomenal conservation is a consequence of a human population's inability to cause resource degradation or a simple observation about long-term equilibrium with resources. It may be a consequence of low population density, limited technology, or consumer demand. Today the term sustainable use or sustainability is nearly iden- tical to epiphenomenal conservation, and it is clear that many tribal populations sustainably extract resources. For example, Redford \& Robinson (1987) compared native versus colonist hunting practices in the Amazon. Through an analysis of hunting yields of 16 native groups and 6 Peruvian and Brazilian backwoodsmen, they showed that colonists had hunted a more restricted set of species and tended to make a more negative impact on game populations because of their greater population density, habitat degradation, catering to extralocal demand, and more efficient technology. Native Amazonians, in comparison, took a wider variety of game, and although they relied on game for a larger fraction of their diet they did not harm game populations as significantly as did colonists.

The term management, on the other hand, does not seem to have an agreed upon definition. In some instances management occurs when individuals take deliberate steps to modify the environment in ways that enhance the availability of resources useful to humans (Balée \& Erickson 2006). Common examples include the practice of burning grasslands to inhibit tree invasion and enhance the density of forage grasses that attract herbivores hunted by humans, as well as a large variety of very specific practices such as those by honey harvesters who leave part of the comb such that the bees may recolonize the hive (Posey 1998). In fact, some historical ecologists argue that although native peoples can be agents of environmental damage, their overall effect is to enhance the environment (Balée \& Erickson 2006, p. 10). Such a claim is deeply problematic because it is based on the premise that enhancement is defined by increased biodiversity. Questions of how, why, and for whom increased biodiversity is beneficial are left unexamined. It is simply assumed to be an unalloyed good.

If conservation and sustainability lead to the same end, why bother to make a distinction between the two? If one historically uses resources on a sustainable basis, but a change occurs, such as increased outside demand 
(fur, skin, and feather trade), reduction of land base, or the introduction of superior technology (shotguns), then resources will likely no longer be taken on a sustainable basis. If, however, a group is practicing true conservation, then there is a much greater chance that the group will be able to adjust to changes in demand, efficiency of capture, or habitat loss.

The critical issue in this debate is an analysis of what people actually do to modify the environment independent of their beliefs about the environment. Many of the critics of so-called new orthodoxy of conservation absence (Headland 1997, Hunn et al. 2003, Nadasdy 2005), shift the debate to considerations of traditional ecological knowledge and environmental beliefs. A particularly striking example of this is Nadasdy's (2005) postmodern claim that conservation is a western concept foreign to the belief systems of Native Americans. Aside from offering scant evidence that this is true for one group (see Hunn et al. 2003, pp. S79-80, for Huna Tlingit for parallels between western and native conservation concepts) or widespread in other indigenous groups, the argument is beside the point. Human impact on resources is the sole claim evaluated by the so-called new orthodoxy. Nadasdy also avers that the definition of conservation is biased, judgmental, and western in construct (2005). Although this claim is somewhat accurate, it is judgmental only in a neutral actuarial sense: A people engages in conservation or it does not. The answer does not lead one to draw any necessary moral conclusion. Although conservation may be a western construct, its origins do not render it faulty or inapplicable. The evidence necessary to decide the debate revolves around human environmental impact and not around human beliefs about the environment and their place it in. This is not to say that beliefs are not worthy of investigation (Hames 1991; Smith \& Wishnie 2000, p. 501) and perhaps even necessary for real conservation. The point is that beliefs and world views are not sufficient.

\section{REACTIONS TO KRECH'S THE ECOLOGICAL INDIAN AND DIAMOND'S COLLAPSE}

Most of the debate regarding the ecologically noble savage has been among scientific researchers in anthropology, conservation biology, and political science. With the publication of Krech's The Ecological Indian, this debate has been joined by humanistically oriented scholars in anthropology and history as well as by political activists (Krech 2005). In 2002 a conference entitled "Re-Figuring the Ecological Indian" was held at the University of Wyoming leading to a volume edited by Harkin \& Lewis (2007). Krech's monograph is a set of historical case studies on Native American impact on deer, beaver, bison, and other important games species as well as a review of the paleontological evidence for the megafaunal overkill and an archaeological analysis of the Hohokam. The goal of Krech's work was to investigate two questions: (a) Were Native American ecologists, and $(b)$ were they conservationists? To the surprise of few, the answer to the first is generally affirmative: They understood complex environmental interactions. But the answer to the second is largely negative: Native Americans made no systematic efforts to conserve game species and historically decimated many of those upon which they depended. The exception appears to be beaver conservation by Algonquian foragers using a territorial harvesting system. However, in the introduction to the volume, editors Harkin and Lewis state that there are meanings behind the ecological Indian not addressed by Krech. They are concerned, for example, with how $\mathrm{Na}$ tive Americans employ ecological nobility for political and ideological support for legitimacy, how nobility relates to identity, and the way Native Americans conceptualized human predatory actions and game responses. Others in the volume (e.g., Dorst 2007) concern themselves with how the image is portrayed by Euro Americans in museum displays and other media. These are odd additions because 
Krech carefully restricted his research to ecological knowledge and human impact on resources. It may be that many of the authors concede Krech's basic finding and have moved on to other topics. Nevertheless, these subsidiary issues loom large in some chapters.

In his opening chapter to the volume, Krech provides an overview of the initial critical reaction to his work (Krech 2007a) and responds to his critics in this volume in "Afterword" (Krech 2007b). Given Krech's research focus one would expect that criticism would involve issues such as, is claim right or wrong, is the answer partial or an oversimplification of a complex process, were proper controls instituted, or is the analysis historically contextualized? Many of the contributors (Burch 2007, Feit 2007a, Flores 2007, Kelly \& Prasciunas 2007) directly evaluate Krech's claims. But the image of Native Americans as conservationists extends well beyond the narrow bounds of academia. It is an essentialized belief about Native Americans promoted by some anthropologists, conservation groups, and the general public (Ridley 1996). This belief is sometimes used by native groups to forage arguments about identity, property rights, sovereignty, and ethical superiority (Krech 1999). This second group of criticisms addresses the potential role that Krech's research (and by extension any research that investigates the reality of cherished beliefs held by political actors) may play on Native American identity, sovereignty, political action, and cultural pride, as well as on Krech's ulterior motivations and goals. As Krech (2007a) notes, the only thing that he and his second group of critics hold in common is that Euro Americans wreaked more ecological damage than did Native Americans.

Many of these contributed chapters support Krech's general claim that Native American practices were not aimed at conservation of resources, especially game. Burch (2007) shows that Native Alaskan hunters drove a number of species to local extinction. He makes an interesting distinction between overkill (killing more than one can use over the short term) and over harvest (killing leading to nonsustainability). As might be expected, the conclusions he draws from an examination of the historical record are complex. Nearly all groups harvested sustainably until the arrival of Europeans. However, with one possible exception, sustainability was not by design. The introduction of breech loading rifles, the high trade value placed on local hides and furs, and perhaps religious conversion led to clear cases of over harvesting. Flores (2007) and Harkin (2007) present data on buffalo hunting and northwest coast salmon fishing, which generally agree with Krech's position.

Feit's contribution (2007a) presents evidence that beavers were indigenously conserved through a system of family hunting grounds thus rejecting Krech's position that conservation was, in part, the result of contact. He provides behavioral evidence that the Cree let areas rest and restrained their taking of various age-sex classes of beaver toward the end of sustainable harvests. The system appears to have been maintained by territorial control of hunting areas by extended family groups. As noted by others (e.g., Hames 1988, Hardin 1968, Smith \& Wishnie 2000), areal control of resources is a necessary prerequisite of conservation whether it be private or communal control. Feit has examined Krech's work in three other places $(2004,2007 a, b)$, where he reflects on some of the political and motivational issues allegedly behind Krech's work. Again, the most contested issue revolves around the historical depth of conservation by Algonquian speakers and the role that Euro Americans may have had in influencing $\mathrm{Al}$ gonquian conservation. Krech believes that conservation and the establishment of family hunting territories is, in part, a consequence of Euro-American contact. Feit believes it was indigenously invented. The important point in this particular debate is to recognize that both Feit and Krech believe that many Algonquians had and currently have a system of conservation designed to maintain beaver populations. 
Ronco's chapter (2007) is by far the most critical and off the mark given Krech's explicit purpose. As Krech (2007a) insightfully notes, "With a rhetorical strategy suitable to a student of environmental law," Ronco shows why he does not like the results. Lawyerly arguments are not aimed at finding the truth or impartially examining the evidence but are subordinated to making a favored case. Ronco argues that ecological legitimacy underlies Native American identity and political leverage, and anything that undercuts these beliefs damages Native Americans. This echoes a statement made by Posey (cited in Ridley 1996, p. 217) in relation to Amazonian people: “...[A]ny evidence of ecologically unsound activities by indigenous and traditional peoples undermines their basic rights to land, resources, and cultural practice" (for a nearly identical statement, see Hunn et al. 2003, p. S8). Ronco's criticism does not hinge on whether Krech is correct or incorrect but how his findings affect the political agendas of $\mathrm{Na}$ tive Americans and their identity. Ronco offers no evidence that Krech's research has had any effect on Native American sovereignty or why it is useful to base one's identity on a false belief (see also Deloria 2000). (But see Wildlife Reserves and the Ecologically Noble Savage below.) The issue switches from the truth or falsity of the empirical claim to its potential positive or negative consequences. If the impact is potentially negative, then findings are questioned or denied.

Ronco's and Feit's chapters partially address what I consider to be a major weakness in Krech's analysis (see also Hunn et al. 2003, p. S81, and Burch 2007). Except for his analysis of the archaeological and paleontological data, Krech is dealing with peoples who have been fundamentally affected by outside forces. With the European invasion of the New World, native peoples were dispossessed of their land, forced into marginal areas or into areas already inhabited by other native peoples, required to share their resources with Euro Americans, witnessed the value of traditional resources reaching astronomical val- ues because of the action of external markets, and acquired superior foreign hunting technology (guns and steel traps). Any of these factors could have transformed a stable system to one headed toward disequilibrium. Burch (2007), in the same volume, nicely illustrates how many of these historical processes transformed Inuit hunting (see also Holt 2005 on the Amazonian Huaorani). Although Krech documents these factors, he does not effectively consider the possibility that they could have destroyed indigenous systems of conservation if they had existed.

Diamond's best seller Collapse (2003) presents a series of case studies of humancaused environmental catastrophes, and it has received much less negative commentary than has Krech's work for perhaps three reasons: Except for one chapter on the Anasazi, it does not focus on Native North America, conservation success stories are given, and many of his examples are from societies more technologically complex than those under the rubric of the ecologically noble savage. He shows that human-caused environmental destruction occurs at all levels of social complexity. Each chapter is a case study documenting different human-caused impacts such as soil erosion, denutrification, and salinization, and a variety of biotic resource overexploitations in all economic formations through just about every way of wresting resources from the environment. At the same time he shows examples of human mitigation of negative exploitation with New Guinea Causirian planting, Japanese post-Tokugawa reforestation, Tikopian pig prohibition, and Polynesian control of reef fishing. Many of the accounts Diamond provides are not new (Easter Island and salinization of prehistoric Middle Eastern agriculture), having been reviewed by archaeologists (e.g., Redman 1999). The strength of the book lies in its willingness to consider all reasonable factors from climatic shifts and biogeography to culturally preferred subsistence and dietary patterns and how they may interact to form a perfect storm. What is missing in Diamond's and others' 
accounts is a coherent explanation of why some groups (e.g., Tikopia) were able to prevent degradation while others (e.g., Vikings on Greenland) did not or could not. The subtitle "how some societies choose to fail or succeed" is a bit disingenuous and contradicted by his own research: Invisible soil salinization suggests that choice is impossible when causes or alternatives are unknown. At this point we really do not need more inventories of successes and failures but rather models that will help us understand the conditions under which societies are able to succeed or fail in stable environmental adaptation. Diamond provides some hints. As he mentions, in some cases causes were unknown. In other cases short-term needs (preventing one's children from starving) precluded conservation over the long term. Dramatic climate change can wreck stable adaptations. The list is long. Diamond suggests that there human ingenuity has its limits, and we cannot make effective cost-benefit decisions after adapting ourselves into an environmental corner.

Hunn et al. (2003), in the context of explicitly criticizing both Krech's Ecological Indian and Diamond's Collapse, presents a case of deliberately designed resource conservation of gull eggs by the Huna Tlingit. After the demonstration, he concludes that "conservation by indigenous communities should be seen not as exceptional but rather as the rule" (p. S99). This generalization is startling given that we seem to have but two possible examples of conservation (this study and Feit's study of the Cree) and a multitude of studies that show no conservation (Smith \& Wishnie 2000).

\section{TRADITIONAL ECOLOGICAL KNOWLEDGE}

Native peoples possess an extensive and deep understanding of their local ecosystem. The fields of ethnoecology and more specifically traditional ecological knowledge (TEK) (Gadgil et al. 1993) have clearly documented this fact for decades. However, when it comes to particular issues, some groups have inaccurate ideas about the causes of resource depletion, the consequences of continued extraction, and the means to increase the abundance of resources in their environments (Borgerhoff Mulder \& Coppolillo 2005, pp. 82-89). This issue is important for those who investiage the reality of conservation. Those who argue that native peoples generally do not conserve resources argue that conservation is a consequence of deliberate acts (restraint from resource taking) designed to yield sustainable harvests through time. Therefore, to some extent knowledge of the causes and consequences of harvests through time is required (Holt 2005). To be sure, this knowledge does not have to be empirically accurate. For example, a belief system that postulated that game spirits cause game species to hide at the bottom of a lake if they are hunted too intensively and that they will reappear only if hunters limit their harvesting is a belief system that could lead to conservation. The dynamics between scarcity and plenty are correctly associated with levels of human predation, but the mechanism (spiritual intervention) is incorrect.

Smith (2001) is one of the few scholars to investigate sharply the cognitive bases of conservation. She notes that if conservation is to occur then conservationists need to have some sort of realistic knowledge of the presence and causes of resource depletion. In her investigation of the Amazonian Machiguenga she asked informants whether game was becoming more scarce through time and the cause of the scarcity. When asked why game had become scarce near the village over time, most answered that game had been scared away or that they were hiding. When asked whether the total amount of animals had remained the same, $81 \%$ said that the numbers had remained the same or actually increased but that they were simply further away from the village than they used to be. Similar results were obtained when the topic switched to fish availability. When asked about fallow 
periods for gardens nearly all underestimated the time necessary for full soil nutrient recovery. Furthermore, explanations of poor yields were attributed not to soil problems in recultivated areas but to poor seeds or "spiritual contamination." She also replicated Alvard's results on game selectivity: Females and pregnant females are hunted as avidly as males. As described elsewhere, in some cases a group believes that certain resources are inexhaustible (Vickers 1995) or that they can be safeguarded by ritual means (Brightman 1993).

Zavaleta's (1999) investigation of Yup'ik waterfowl hunting presents a carefully crafted case for indigenous conservation in modern times. Not only does she examine historical data on Yup'ik predation and understanding of waterfowl population dynamics and governmental regulation, but she presents unique data on Yup'ik motivation for conservation. In regards to motivation, she determined that while some hunters simply followed federal regulatory law most others were clearly positively motivated to conserve for the future. This is a convincing case of true conservation emerging in a traditional community and her holistic approach to the problem serves as a powerful model for others to emulate.

\section{WILDLIFE RESERVES AND THE ECOLOGICALLY NOBLE SAVAGE}

The ecologically noble savage has two political dimensions. The first addresses how this concept is used by native peoples to identify essential characteristics of their culture and world view and how it is deployed politically in their struggles for self determination and equality. The second concerns how native peoples are used by conservation organizations to advance the organizations' agendas and the current struggle between native peoples and conservation organizations. Beginning with the second dimension first, the relationships between native peoples and international conservation non- governmental organizations (NGOs) has been marked by initial collaboration and now by growing estrangement (Chapin 2004). Collaboration with conservation groups perhaps reached its height around the time of The Earth Summit in Rio de Janeiro in 1992. At the summit many NGOs used native peoples to advance their agendas by using them as exemplars of cultures with a strong conservation ethic. According to Conklin (1997)

\begin{abstract}
Amazonian Indians are represented as guardians of the forest, natural conservationists whose cultural traditions and spiritual values predispose them to live in harmony with the earth. A kind of essentialist image is created suggesting that primitive peoples are homogenous entities fixed in time. To be sure some native leaders welcomed this image and helped promote it both because of the struggles they were facing dealing with appropriation of their lands and from an appreciation that conservationists could aid them in their struggles. However, this image is false, maintained through symbolic activities of a few native representatives, and puts the interests of native peoples at odds with their national governments especially as it relates to their sensitivities of outside intervention. (p. 713)
\end{abstract}

During this period native representatives were paraded before major environmental conferences as authentic noble savages who knew the secrets of effective conservation. In the end, conservationists and NGOs created an image of native peoples that does not correspond to their past and certainly does not accurately represent native peoples as a whole (Brosius 1999, pp. 280-81). This image is designed to engender donations and support because it corresponds to preexisting values of first-world donors and their supporters. Today the situation has changed considerably. Leadership at the major conservation organizations (World Wildlife Fund, Nature Conservancy, and Conservation International) often views native peoples as problematic in 
relationship to their establishment of protected conservation areas throughout the world (Conklin \& Graham 1995). The exchanges generated by Schwartzman et al. in Conservation Biology (2000; see responses by Chicchón 2000, Colchester 2000, Redford \& Sanderson 2000, Terborgh 2000) revolve around whether native peoples and parks can coexist. All those involved in this exchange seem to believe that evidence shows native peoples do less damage to wildlife than do nonnatives. For example, Rudel et al. (2002) show that large areas of forest have been transformed into pasture lands by both colonists and Jivaroans but that Jivaroans do less environmental damage through their greater emphasis on horticultural pursuits over livestock. Schwartzman et al. claim that native peoples have never caused the local extinction of species, a claim effectively countered by Redford \& Sanderson (2000) and Chicchón (2000). The central issue they wrestle with is the role traditional peoples can and should play in the development and security of wildlife preserves (Robinson \& Bennett 2000).

At a more extreme end, some in the conservation community use ethnographic research to argue that because native peoples do not conserve resources they should be removed from areas to be conserved. In another venue, Terborgh (1999) calls for "a carefully constructed and voluntary relocation program" (p. 56). The problem here is that a call for voluntary relocation frequently ends up as either a coercive program or a failure to relocate native peoples in a suitable place.

As expected, Chapin's provocative critique of the big three wildlife conservation organizations in World Watch (2004) drew more letters to the editor than had any other article they published (Flavin 2005). Chapin (2004) claimed that the major conservation organi- zations (World Wildlife Fund, Conservation International, and Nature Conservancy) were damaging the lives of rural and native peoples in the planning, establishment, and maintenance of reserves. In effect, they were creating "conservation refugees." He forcefully points out that safeguarding the rights of local peoples is a matter of social justice that ought to be a fundamental component of conservation efforts and that pragmatically the cooperation of local peoples is integral to successful conservation efforts (p. 30). Many of the responses from the major conservation groups were somewhat conciliatory, noting that they had begun to enact some of the reforms and safeguards suggested by Chapin. This situation merits monitoring by anthropologists and other social scientists who are expert in assessing social and economic impacts of conservation projects.

\section{CONCLUSION}

The ecologically noble savage debate has entered a new phase. Following a strict definition of conservation as advocated by behavioral ecologists and conservation biologists, one can conclude that conservation by native peoples is uncommon. Still, it is important to understand fully the factors that permit or work against conservation if we are going to make sensible recommendations to bureaucracies interested in conservation. The issue will move to a more detailed consideration of how people manage (Balée \& Erickson 2006) or engineer (Smith \& Wishnie 2000) their environment and how management or engineering affects ecosystem stability and biodiversity. It may also lead to a renewed and refined interest in how native peoples conceptualize their place in nature and the degree to which that conceptualization affects their conduct toward the environment.

\section{DISCLOSURE STATEMENT}

The author is not aware of any biases that might be perceived as affecting the objectivity of this review. 


\section{LITERATURE CITED}

Alvard M. 1993. Testing the "ecologically noble savage" hypothesis: interspecific prey choice by Piro hunters of Amazonian Peru. Hum. Ecol. 21:355-87

Alvard M. 1994. Conservation by native peoples: prey choice in a depleted habitat. Hum. Nat. $5: 127-54$

Alvard M. 1998. Evolutionary ecology and resource conservation. Evol. Anthropol. 7:62-74

Balée W, Erickson C. 2006. Time, complexity, and historical ecology. In Time and Complexity in Historical Ecology, ed. W Balée, C Erickson, pp. 1-17. New York: Columbia Univ. Press

Boehm C. 1999. Hierarchy in the Forest. Cambridge, MA: Harvard Univ. Press

Borgerhoff Mulder M, Coppolillo P. 2005. Conservation: Ecology, Economics, and Culture. Princeton, NJ: Princeton Univ. Press

Brightman R. 1993. Grateful Prey: Rock Cree Human-Animal Relationships. Berkeley: Univ. Calif. Press

Brosius P. 1999. Analyses and interventions. Curr. Anthropol. 40:277-309

Buege D. 1996. The ecologically noble savage revisited. Environ. Ethics 18:71-88

Burch E. 2007. Rationality and resource use among hunters: some Eskimo examples. In Native Americans and the Environment: Perspectives on the Ecological Indian, ed. M Harkin, Dr Lewis, pp. 123-54. Lincoln: Univ. Neb. Press

Chapin M. 2004. A challenge to conservationists. World Watch Nov./Dec.:12-31

Chicchón A. 2000. Conservation theory meets practice. Conserv. Biol. 14:1368-69

Colchester M. 2000. Self-determination or environmnetal determinism for indigenous peoples in tropical forest reserves. Conserv. Biol. 14:1365-67

Conklin B. 1997. Body paint, feathers, and VCRs: Aesthetics and authenticity in Amazonian activism. Am. Ethnol. 24:711-37

Conklin B, Graham L. 1995. The shifting middle ground: Amazonian Indians and eco-politics. Am. Antbropol. 97:695-710

Deloria V. 2000. The speculations of Krech. Worldviews 4:283-93

Diamond J. 1986. The environmentalist myth. Nature 324:19-20

Diamond J. 2003. Collapse: How Societies Choose to Succeed or Fail. New York: Viking

Dorst J. 2007. Watch for fall bison: the buffalo hunt as museum trope and ecological allegory. In Native Americans and the Environment: Perspectives on the Ecological Indian, ed. M Harkin, D Lewis, pp. 173-91. Lincoln: Univ. Neb. Press

Edgerton R. 1992. Sick Societies: Challenging the Myth of Primitive Harmony. New York: The Free Press

Ellingson T. 2001. The Myth of the Noble Savage. Berkeley: Univ. Calif. Press

Feit H. 2004. Les territoires de chasse algonquiens avant leur 'découverte'? Études et histoires sur les tenures, les incendies de forêt et la sociabilité de la chasse. Rech. Amérindiennes Québec 34:5-21

Feit H. 2007a. Myths of the ecological whitemen. In Native Americans and the Environment: Perspectives on the Ecological Indian, ed. M Harkin, DR Lewis, pp. 52-94. Lincoln: Univ. Neb. Press

Feit H. 2007b. Objectivity, advocacy, and trust in Shepard Krech's Ecological Indian. In Anthropology, First Nations and Law, ed. M Pinkoski. Vancouver: Univ. B.C. Press. In press

Flavin C. 2005. A challenge to conservationists II. World Watch Jan./Feb.:5-20

Flores D. 2007. Wars over buffalo. In Native Americans and the Environment:Perspectives on the Ecological Indian, ed. M Harkin, D Lewis, pp. 153-72. Lincoln: Univ. Neb. Press

Gadgil M, Berkes F, Folke C. 1993. Indigenous knowledge for biodiversity conservation. AMBIO 22:151-56 
Hames R. 1988. Game conservation or efficient hunting. In Capturing the Commons: Anthropological Approaches to Resource Management, ed. B Mccay, J Acheson, pp. 192-207. Tucson: Univ. Ariz. Press

Hames R. 1991. Wildlife conservation in tribal societies. In Biodiversity: Culture, Conservation, and Ecodevelopment, ed. M Oldfield, J Alcorn, pp. 172-99. Denver, CO: Westview

Hardin G. 1968. The tragedy of the commons. Science 162:1243-48

Harkin M, Lewis D, eds. 2007. Native Americans and the Environment: Perspectives on the Ecological Indian. Lincoln: Univ. Neb. Press

Harris M. 1968. The Rise of Anthropological Theory. New York: Thomas Crowell

Harris M. 1974. Cows, Pigs, Wars and Witches. New York: Vintage

Hayashida F. 2005. Archaeology, ecological history, and conservation. Annu. Rev. Anthropol. $34: 43-65$

Headland T. 1997. Revisionism in ecological anthropology. Curr. Anthropol. 38:605-23

Holt F. 2005. The catch-22 of conservation: indigenous peoples, biologists, and cultural change. Hum. Ecol. 33:199-215

Hunn E. 1982. Mobility as a factor limiting resource use in the Columbian Plateau of North America. In Resource Managers: North American and Australian Foragers, ed. N Williams, E Hunn, pp. 17-43. Denver, CO: Westview Press

Hunn E, Johnson D, Russell P, Thornton T. 2003. Huna Tlingit traditional environmental knowledge, conservation, of a "wilderness" park. Cult. Anthropol. 44:s79-103

Keeley L. 1995. War Before Civilization: The Myth of the Peaceful Savage. Oxford: Oxford Univ. Press

Kelly R, Prasciunas M. 2007. Did the ancestors of Native Americans cause animal extinctions in Late-Pleistocene North America. In Native Americans and the Environment: Perspectives on the Ecological Indian, ed. M Harkin, D Lewis, pp. 95-122. Lincoln: Univ. Neb. Press

Krech S. 1981. Indians, Animals, and the Fur Trade. Athens, GA: Univ. Ga. Press

Krech S. 1999. The Ecological Indian: Myth and History. New York: Norton

Krech S. 2005. Reflections on conservation, sustainability, and environmentalism in indigenous North America. Am. Antbropol. 107:78-86

Krech S. 2007a. Afterword. In Native Americans and the Environment: Perspectives on the Ecological Indian, ed. M Harkin, Dr Lewis, pp. 343-54. Lincoln, NE: Univ. Nebraska Press

Krech S. 2007b. Beyond the Ecological Indian. In Perspectives on the Ecological Indian: Native Americans and the Environment, ed. M Harkin, DR Lewis, pp. 3-31. Lincoln: Univ. Neb. Press

LeBlanc S. 2003. Constant Battles: The Myth of the Peaceful, Noble Savage. New York: St. Martin's Press

Lyman R, Cannon K, eds. 2004. Adding Prehistory to Conservation Biology: Zooarchaeological Studies from North America. Salt Lake City: Univ. Utah Press

Meggers B. 1971. Amazonia: Man and Culture in a Counterfeit Paradise. Chicago: Walter de Gruyter

Miller G, Fogel M, Magee J, Gagan M, Clarke S, et al. 2005. Ecosystem collapse in Pleistocene Australia and human role in megafaunal extinction. Science 309:287-90

Nadasdy P. 2005. Transcending the debate over the ecologically noble Indian: indigenous peoples and environmentalism. Ethnobistory 52:291-331

Odum H. 1972. Environment, Power, and Society. New York: Wiley

Orlove B, Brush S. 1996. Anthropology and the conservation of biodiversity. Annu. Rev. Anthropol. 25:329-52 
Posey D. 1998. Diachronic ecotones and anthropogenic landscapes in Amazonia: contesting the consciousness of conservation. In Advances in Historical Ecology, ed. W Balée, pp. 104-18. New York: Columbia Univ. Press

Rambo A. 1985. Primitive Polluters: Semang Impact on the Malaysian Tropical Rain Forest Ecosystem. Anthropol. Pap. No. 76, Mus. Anthropol. Ann Arbor: Univ. Mich. Press

Rappaport R. 1983. Pigs for the Ancestors. New Haven, CT: Yale Univ. Press

Redford K. 1991. The ecologically noble savage. Orion 9:24-29

Redford K, Robinson J. 1987. The game of choice: patterns of Indian and colonist hunting in the neotropics. Am. Anthropol. 89:650-66

Redford K, Sanderson S. 2000. Extracting humans from nature. Conserv. Biol. 14:1362-64

Redman C. 1999. Human Impact on Ancient Environments. Tuscon: Univ. Ariz. Press

Ridley M. 1996. The Origins of Virtue. London: Viking, Penguin

Robinson J, Bennett E, eds. 2000. Hunting for Sustainability in Tropical Forests. New York: Columbia Univ. Press

Ronco D. 2007. The ecological Indian and the politics of representation. In Native Americans and the Environment Perspectives on the Ecological Indian, ed. M Harkin, D Lewis, pp. 32-51. Lincoln: Univ. Neb. Press

Rudel T, Bates D, Machiguiashi R. 2002. Ecologically noble Amerindians? Cattle ranching and cash cropping among Shiwar and colonists in Ecuador. Latin Am. Res. Rev. 37:144-59

Ruttan L, Mulder M. 1999. Are East African pastoralists truly conservationists? Curr. Anthropol. 40:621-52

Schwartzman S, Moreira A, Nepstad D. 2000. Rethinking tropical forext conservation: perils in parks. Conserv. Biol. 14:1351-57

Slobodkin L. 1974. Prudent predation does not require group selection. Am. Nat. 108:665-78

Smith E. 1983. Anthropological applications of optimal foraging theory: a critical review. Curr. Anthropol. 24:625-51

Smith E, Wishnie M. 2000. Conservation and subsistence in small-scale societies. Annu. Rev. Anthropol. 29:493-524

Smith N. 2001. Are indigenous peoples conservationists? Rational. Soc. 13:229-61

Stahl P. 1996. Holocene biodiversity: an archaeological perspective from the Americas. Аnпи. Rev. Anthropol. 25:105-26

Steadman D, Martin P, Macphee R, Jull A, Mcdonald H, et al. 2005. Asynchronous extinction of late Quaternary sloths on continents and islands. Proc. Natl. Acad. Sci. USA 102:11763-68

Stearman A. 1994. "Only slaves climb trees": revisiting the myth of the ecologically noble savage in Amazonia. Hum. Nat. 5:339-57

Stewart J, Kolfschoten T, Markova A, Musil R. 2004. Neanderthals as Part of the Broader Late Pleistocene Megafaunal Extinctions? Neanderthals and Modern Humans in the European Landscape: During the Last Glaciation. Cambridge, UK: McDonald Inst. Monogr., Cambridge Univ.

Stoffle R. 2005. Places that count: traditional cultural properties in cultural resource management; tribal cultural resource management: the full circle to stewardship. Am. Anthropol. 107:138-40

Surovell T, Waguespack N, Brantingham P. 2005. Global archaeological evidence for proboscidean overkill. Proc. Natl. Acad. Sci. USA 102:6231-36

Terborgh J. 1999. Requiem for Nature. Washington, DC: Island/Shearwater

Terborgh J. 2000. The fate of tropical forests: a matter of stewardship. Conserv. Biol. 14:1358-61

True C, Field J, Dortch D, Charlels B, Wroe S. 2005. Prolonged existence of humans and megafauna in Pleistocene Australia. Proc. Natl. Acad. Sci. USA 102:8381-85 
Vickers W. 1995. From opportunism to nascent conservation: the case of the Siona-Secoya. Hum. Nat. 5:307-37

Wynne-Edwards V. 1962. Animal Dispersion in Relation to Social Behavior. Edinburgh: Boyd \& Oliver

Zavaleta E. 1999. The emergence of waterfowl conservation among Yup'ik hunters in the Yukon-Kuskokwim Delta, Alaska. Hum. Ecol.27:231-266 